\title{
COMPARATIVE STUDY OF TWO HELIX ASPERSA EXTRACTS ON TUMOR CELL LINES (HUT-78 AND SEAX) PROLIFERATION AND MMP-9 SECRETION
}

\author{
MEBIROUK ROMEILA*1,2, NAIMI DALILA*2,4, RIANI MERIEM ${ }^{3}$, ANTONICELLI FRANK ${ }^{3}$
}

${ }^{1}$ Department of Animal Biology, Faculty of Life and Natural Sciences, Frères Mentouri University (FMU)-Constantine BP 325, Route de Ain El Bey, Constantine, 25017 Algeria, ${ }^{2}$ Laboratory of Microbiological Engineering and Applications (FMU), ${ }^{3}$ Laboratory of Dermatology, UFR Médecine and Odontologie, 51 Rue Cognacq-Jay 51095 Reims Cedex University of Reims Champagne Ardenne (URCA), France, ${ }^{4}$ Higher National School of Biotechnology of Constantine, Nouveau Pôle Universitaire Ali Mendjeli, BP E66, 25100 Constantine, Algeria Email: dalila.naimi76@gmail.com

Received: 24 Jul 2016 Revised and Accepted: 21 Sep 2016

\begin{abstract}
Objective: Despite the progress in cancer research, current therapies are ineffective and cause many adverse effects. The discovery of new natural anti-tumor agents that can act on multiple mechanisms of growth and tumor invasion with minor side effects and which can be safe for patients. Therefore, we sought new natural products from an invertebrate organism belonging to the phylum of mollusks: a land snail, Helix aspersa. This study was aimed to evaluate the cytotoxic activity of two extracts prepared from Helix aspersa, on two cutaneous T cell lymphoma cell line (HUT-78 and SeAx). Their effect on MMP-9 expression was also tested.
\end{abstract}

Methods: We prepared from the snail Helix aspersa: an aqueous (AE) and a hydroalcoholic extracts (HAE). We have evaluated the concentration of total proteins and total phenols in these extracts. The percentage of cell mortality was evaluated after incubating the cell lines with the two extracts at different concentrations, by using trypan blue exclusion method. Finally, the tumor cells expression of metalloproteinase MMP-9 was examined by zymography analysis.

Results: We have found that $1 \mathrm{mg} / \mathrm{ml}$ of AE contains $(4.53 \pm 0.48 \mathrm{mg})$ of total proteins and $(2.44 \pm 0.11 \mathrm{mg}) \mathrm{GAE} \mathrm{g}{ }^{-1}$ of phenols. $1 \mathrm{mg} / \mathrm{ml}$ of $\mathrm{HAE}$ contains $(1.83 \pm 0.23 \mathrm{mg})$ of total proteins and $(2.81 \pm 0.16 \mathrm{mg}) \mathrm{GAE} \mathrm{g}^{-1}$ of phenols. On one hand, both extracts exerted a toxic effect on these tumor cells. Indeed, aqueous extract induced $44.09 \%$ mortality in HUT-78 and $31.47 \%$ mortality in SeAx tumor cell line with $50 \mu \mathrm{g} / \mathrm{ml}$. While, the hydroalcoholic extract induced $29.90 \%$ in HUT-78 and $25 \%$ in SeAx. On the other hand, the result showed no changes of MMP-9 expression.

Conclusion: Helix aspersa's extracts had a toxic effect on cutaneous T cell lymphoma (CTCL), but did not inhibit the production of the protease by these two cell lines in culture.

Keywords: Helix Aspersa extracts, HUT-78 cell line, SeAx cell line, Cytotoxicity, MMP-9 expression

(C) 2016 The Authors. Published by Innovare Academic Sciences Pvt Ltd. This is an open access article under the CC BY license (http://creativecommons.org/licenses/by/4. 0/) DOI: http://dx.doi.org/10.22159/ijpps.2016v8i11.14275

\section{INTRODUCTION}

Helix aspersa is a terrestrial pulmonate gastropod of the helicidae family. It is the most widely cultivated specie and most profitable economically. It is an important source of protein and microelements (salt, copper, iron, phosphor, and selenium) [1, 2] Deficiency of certain microelements can be responsible for an increased risk in many diseases, such as: cardiovascular diseases, several forms of cancer, immunodeficiency, and allergies. Many studies confirmed in human nutrition, the potential quality of the protein content issued from snail. However, its importance in human therapeutics is poorly documented.

Helix aspersa is widespread in the world because of its adaptability against climatic and environmental stress conditions. This assumes that the snail would produce chemical substances against many dangers it would face mobile predators, invading microorganisms and parasites. Therefore, we explored and evaluated the effects of two snail's extracts against proliferation of two tumor cell lines of cutaneous lymphomas named HUT-78 and SeAx.

During the various stages of tumor development, the malignant cells acquire several mechanisms that favor tumor growth and invasion to other tissues. The ability of tumor cells to migrate through the extracellular matrix (ECM) has been partly attributed to their capacity to secret some proteases called matrix metalloproteinase (MMPs). MMPs are a family of which the first enzyme was discovered in 1962 [3]. These enzymes are endopeptidase zinc-dependent and have high-affinity for binding sites of ECM components. They are mainly produced by inflammatory cells such as macrophages, neutrophils, mast cells, dendritic cells and T cells. $[4,5]$. They are also associated with invasion and metastasis [6]. [6]. Many studies showed the link between the irregularity of the expression of MMPs and cancer development [7-9]. They have received close attention since their production increased and appeared to correlate with the malignant potential of several types of cancer, including cutaneous lymphoma. Especially, an increase of MMP-9 mRNA, a type IV collagenase of 92 $\mathrm{kDa}$ à éliminer [10]. In the tumor cells of non-Hodgkin lymphoma $[10,11]$.

It is known that the growth and migration of tumor cells is the result of a dysfunction of the molecular machinery leading to the resistance of the tumor cell to apoptosis. This results in an increasedproliferative capacity, which associated with an increased MMP secretion favors, metastasis dissemination.

In this study we investigated in the first step the capacity of snail extracts (AE and HAE) to inhibit the proliferation of two cutaneous lymphomas cell lines HUT-78 and SEAX. In the second step we checked the effects of snail extracts on "MMP-9" secretion from these cell lines, using zymography technique.

\section{MATERIALS AND METHODS}

\section{Preparation of Helix aspersa extracts}

Helix aspersa was collected during the spring season in different regions of eastern Algeria. The animals were kept in the laboratory at room temperature $\left(25^{\circ} \mathrm{C}\right)$, and fed lettuce, cucumber and carrot. The extraction was performed according to the protocol elaborated by El-Wahidi M et al., 2011 [12] and modified by us. Briefly, the gastropod Helix aspersa is stripped of its shell, and its visceral mass 
is removed. The foot and the head were recovered, crushed and homogenized using a homogenizer (DAIHAN scientificHG15A090331601) at a rate of $20 \mathrm{t} / \mathrm{min}$ for $20 \mathrm{~min}$. The homogenate obtained was lyophilized (Freeze drayer Labconco, France) (heat at $56{ }^{\circ} \mathrm{C}$, Vacuum 0.9 mbar). The freeze-dried Helix aspersa was extracted three times in distilled water, and filtered on büchner. The filtrates obtained from the aqueous extract (AE) were frozen at- $30{ }^{\circ} \mathrm{C}$ until use. The resulting pellet was extracted once with ethanol $80 \%$ and twice with absolute ethanol, filtered on büchner. The filtrates were combined and alcohol was fully evaporated using a rotary evaporator (at $40{ }^{\circ} \mathrm{C}$ ). The suspension obtained was adjusted with distilled water to a volume of $55 \mathrm{ml}$ then, extracted three times with the same volume of dichloromethane.

The two phases, aqueous and organic, were separated using a separatory funnel. The aqueous phase was frozen at-30 ${ }^{\circ} \mathrm{C}$ and constitutes the extract $\mathrm{HAE}$. The aqueous extract $\mathrm{AE}$ and hydroalcoholic extract HAE were lyophilized, to be subsequently diluted in culture medium RPMI 1640 and sterile buffer (PBS) respectively.

\section{Estimation of total proteins and total phenolic content in the} aqueous extract and hydroalcoholic extract

Total proteins content in aqueous extract and hydroalcoholic extract was determined by the Bradford method [13]. Total phenolics content in aqueous and hydroalcoholic extracts were determined by the method elaborated by Vermerris and Nicholson 2006 [14].

\section{Cell culture}

HUT-78 and SeAx cell lines were kindly provided by Dr Michel L (INSERM S 976, France). HUT-78 and SeAx are cutaneous T cell lymphoma, chosen because they are defective in apoptosis. Both HUT-78 and SEAX were maintained culture in RPMI 1640 medium, Gluta MAX supplement (Gibco-61870044), supplemented with $10 \%$ decomplemented fetal bovine serum (Gibco-10270-106) and $1 \%$ of antibiotics (penicillin and streptomycin). All cell lines were grown in 24-well tissue culture plates at $37{ }^{\circ} \mathrm{C}$ in a humidified atmosphere with $5 \% \mathrm{CO}_{2}$ at $2 \times 10^{5}$ cells $/ \mathrm{ml}$ in complete medium. For activation experiments, cell cultures were treated with snail extracts for $24 \mathrm{~h}$.

\section{Toxicity test}

To evaluate the number of alive and dead cells, the cells were stained with $0.2 \%$ trypan blue (Gibco-15250061) and counted on a hemocytometer. The cytotoxicity assay was performed to test the ability of the two extract "AE" and "HAE" to kill cancer cells. Cells stained in blue following trypan blue uptake were interpreted as nonviable.

Cell viability experiments were performed as follow: $250 \mu \mathrm{l}$ of the cell suspension of the two lines at a concentration of 2 million cells per ml were incubated $24 \mathrm{~h}$ with different concentrations of each extracts previously filtered on a $0.2 \mu \mathrm{m}$ filter. After $24 \mathrm{~h}$ of incubation, the cells were harvested. $10 \mu \mathrm{l}$ of trypan blue at $0.8 \%$ was added to $90 \mu \mathrm{l}$ of each cell suspension. After $2 \mathrm{~min}$, the number of stained cells and the total number of cells were counted to determine the percentage of death in each condition of stimulation.

\section{Hoechst test (evaluation of chromatin condensation)}

It is possible to detect apoptosis, through the dye Hoechst 33342 (Trihydrochloride, Trihydrate, $10 \mathrm{mg} / \mathrm{ml}$ Solution in Watermolecular probes, H3570), a fluorescent dye that stains DNA. Apoptosis was evaluated by the degree of chromatin condensation determined by fluorescence staining of living and dead cells according to the protocol given by the manufacturer (Molecular probes). The Hoechst staining method was as following:

- After stimulation of the two lines HUT-78 and SeAx with the respective extracts at a concentration of $50 \mu \mathrm{g} / \mathrm{ml}$ for $24 \mathrm{~h}$, cells were pelleted and re-suspended in $100 \mu \mathrm{l}$ with the diluted Hoechst reagent (1:50 in RPMI 1640 with $1 \%$ antibiotic).

- Hoechst staining was visualized on $20 \mu$ l of cell suspension deposited on a slide.
- Finally, cells nuclei were observed under a fluorescence microscope (Leica DM2500).

\section{Gel zymography}

T-cell lymphoma HUT-78 and SeAx cells were seeded at a concentration of 2 million cells per $\mathrm{ml}$ on plastic plates and stimulated in a serum-free conditioned medium, with snail extracts. Cultures media were harvested after $24 \mathrm{~h}$ and separated through a $10 \%$ sodium dodecyl sulfate (SDS)-polyacrylamide gel containing 1 $\mathrm{mg}$ per $\mathrm{ml}$ gelatin as substrate. Following electrophoresis (PROTEAN ${ }^{\circledR}$ Tetra Vertical Electrophoresis Cell, biorad), the gels were washed in $2.5 \%$ Triton X-100 for $1 \mathrm{~h}$ at room temperature; further incubated at $37{ }^{\circ} \mathrm{C}$ overnight in $50 \mathrm{mmol}$ Tris- $\mathrm{HCl}, 5 \mathrm{mmol}$ $\mathrm{CaCl}_{2}, 200 \mathrm{mmol} \mathrm{NaCl}$ (pH 7.6); stained with Coomassie blue G-250 $(0.1 \%)$; and destained in methanol/acetic acid/water (20/10/70; vol/vol/vol). MMP gelatinolytic activity was evidenced as white zones of lysis.

Aqueous and hydroalcoholic extracts from the terrestrial mollusk were tested at the following concentrations: $1 \mu \mathrm{g} / \mathrm{ml}, 5 \mu \mathrm{g} / \mathrm{ml}, 10$ $\mu \mathrm{g} / \mathrm{ml}$ and $50 \mu \mathrm{g} / \mathrm{ml}$. Supernatant of untreated tumor cells was considered as control.

\section{Statistical analysis}

The values are expressed as mean \pm standard error of the mean. For comparison of different groups, $p$-values were calculated with student's t-test. In all cases $p<0.05$ was considered to be statistically significant.

\section{RESULTS}

Estimation of proteins and total phenolic in aqueous extract and hydro alcoholic extract

Total protein and total phenolic contents of Helix aspersa extracts tested for each extract are summarized in fig. 1. As can be observed, the quantity of proteins in aqueous extract was $(1.83+-0.23 \mathrm{mg} / \mathrm{ml}$, $\mathrm{p}=0.005)^{\mathrm{GAE} \mathrm{g}^{-1}}$ in hydroalcoholic crude extract (fig. 1).

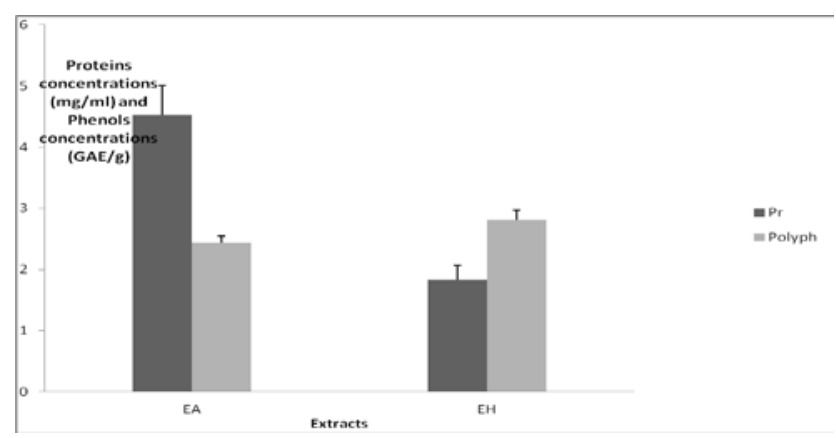

Fig. 1: Level of protein and total phenol content in aqueous and hydroalcoholic extracts of Helix aspersa

Pr: proteins, polyph: polyphenols

\section{Cytotoxic effects of Helix aspersa's extracts}

\section{Effects of aqueous extract on two lymphoma cell lines}

HUT-78 and SEAX cells were cultured at a concentration of 2 million cells $/ \mathrm{ml}$. The mortality percentage of cancer cells was evaluated using trypan blue following cell stimulation with aqueous and hydroalcoholic extracts at different concentrations for $24 \mathrm{~h}$. Effects of extracts were evaluated in triplicate. The number of dead cells was determined in each well. The cytotoxicity assay showed a significant increase in the number of dead cells in the culture medium supplemented with $\mathrm{AE}$ compared to control cultures. Compared with untreated cells $(14.44 \pm 0.69 \%)$, the mean percentage of cell death at the end of incubation increased up to $(17.59 \pm 2.42 \%$, $\mathrm{p}=0.006)$ with $1 \mu \mathrm{g} / \mathrm{ml},(25.82 \pm 3.26 \%, \mathrm{p}=0.005)$ with $5 \mu \mathrm{g} / \mathrm{ml}$, 
(25.19 $\pm 5.44 \%, \mathrm{p}=0.004)$ with $10 \mu \mathrm{g} / \mathrm{ml}$ and finally $(44.09 \pm 3.89 \%$, $\mathrm{p}=0.003$ ) with $50 \mu \mathrm{g} / \mathrm{ml}$ of AE in HUT-78 (fig. 2), and (18.21 $\pm 3.46 \%$, $\mathrm{p}=0.012)$ with $1 \mu \mathrm{g} / \mathrm{ml},(24.11 \pm 5.06 \%, \mathrm{p}=0.014)$ with $5 \mu \mathrm{g} / \mathrm{ml}$, $(27.67 \pm 5.44 \%, \quad \mathrm{p}=0.013)$ with $10 \mu \mathrm{g} / \mathrm{ml}$, and $(31.47 \pm 2.96 \%$, $\mathrm{p}=0.003)$ in SeAx cell line compared to untreated cells (12.14 $\pm 1.05 \%$ ) (fig. 2).

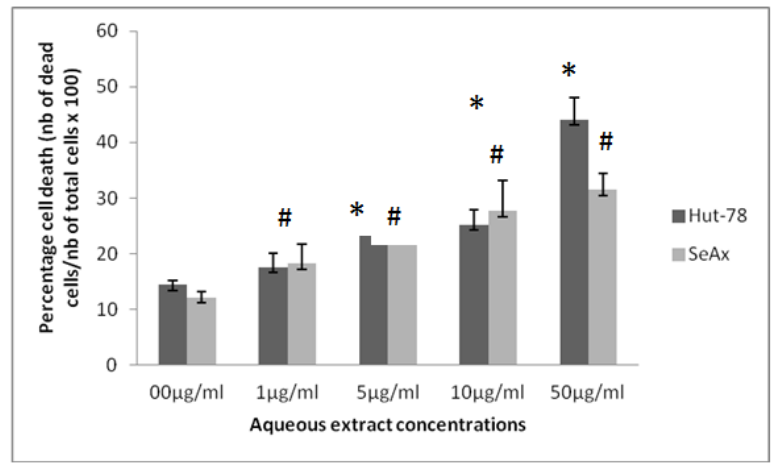

Fig. 2: Effects of different concentrations of aqueous extract on Hut-78 and SeAx cell death after $24 \mathrm{~h}$ of incubation, ${ }^{*} p \leq 0.05$ compared to control cultures of HUT-78. \#p $\leq 0.05$ compared to control cultures of SeAx

Effects of hydro alcoholic extract on two lymphoma cell lines

We also observed a significant increase in cell mortality of the two lines upon treatment with HAE compared to untreated cells $(14.44 \pm 0.69 \%)$; HAE treatment enhanced cell mortality up to (20.47 $\pm 5.53 \%, p=0.023),(20.81 \pm 3.44 \%, p=0.009),(24.24 \pm 6.17 \%$, $\mathrm{p}=0.021)$ and, $(29.90 \pm 5.98 \%, \mathrm{p}=0.013)$, when used at $1 \mu \mathrm{g} / \mathrm{ml}, 5$ $\mu \mathrm{g} / \mathrm{ml}, 10 \mu \mathrm{g} / \mathrm{ml}$ and $50 \mu \mathrm{g} / \mathrm{ml}$ respectively in HUT-78 cell line (fig. $3)$. However, the observed cell mortality was of $(18.84 \pm 1.47 \%$, $\mathrm{p}=0.002)$ with $1 \mu \mathrm{g} / \mathrm{ml},(21.31 \pm 2.21 \%, \mathrm{p}=0.004)$ with $5 \mu \mathrm{g} / \mathrm{ml}$, $(23.41 \pm 2.25 \%, \mathrm{p}=0.003)$ with $10 \mu \mathrm{g} / \mathrm{ml}$ and $(25 \pm 5.57 \%, \mathrm{p}=0.016)$ with $50 \mu \mathrm{g} / \mathrm{ml}$ as compared to untreated SeAx cells (12.14 \pm 1.05$)$ (fig. 3).

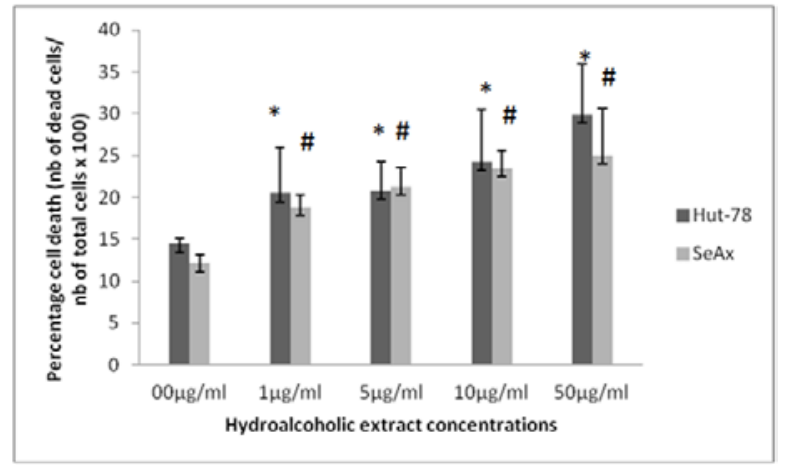

Fig. 3: Effects of different concentrations of alcoholic extract on Hut-78 and SeAx cell death after $24 \mathrm{~h}$ of incubation, ${ }^{*} \mathrm{p} \leq 0.05$ compared to control cultures of HUT-78. \#p $\leq 0.05$ compared to control cultures of SeAx

\section{Chromatin condensation}

To further the type of cell cytotoxicity induced by the aqueous extract corresponded to cells necrosis or apoptosis, a marking of the cell nuclei was performed with the DNA counter stain hoechst dye. Cell staining observed by fluorescence microscopy showed that treatment of the 2 cell lines HUT-78 and SEAX stimulated with AE at $50 \mu \mathrm{g} / \mathrm{ml}$ for $24 \mathrm{~h}$ caused a fragmentation of nuclei (yellow arrows, fig. 4B and 4D) and chromatin condensation (fig. 4 B and 4 D) respectively; as compare with untreated tumor cells HUT-78 and $\mathrm{SeAx}$ (fig. $4 \mathrm{~A}$ and $4 \mathrm{C}$ ) that exhibit normal morphology of nuclei except few cells of HUT-78 cell line (red arrow in fig. 4 A).
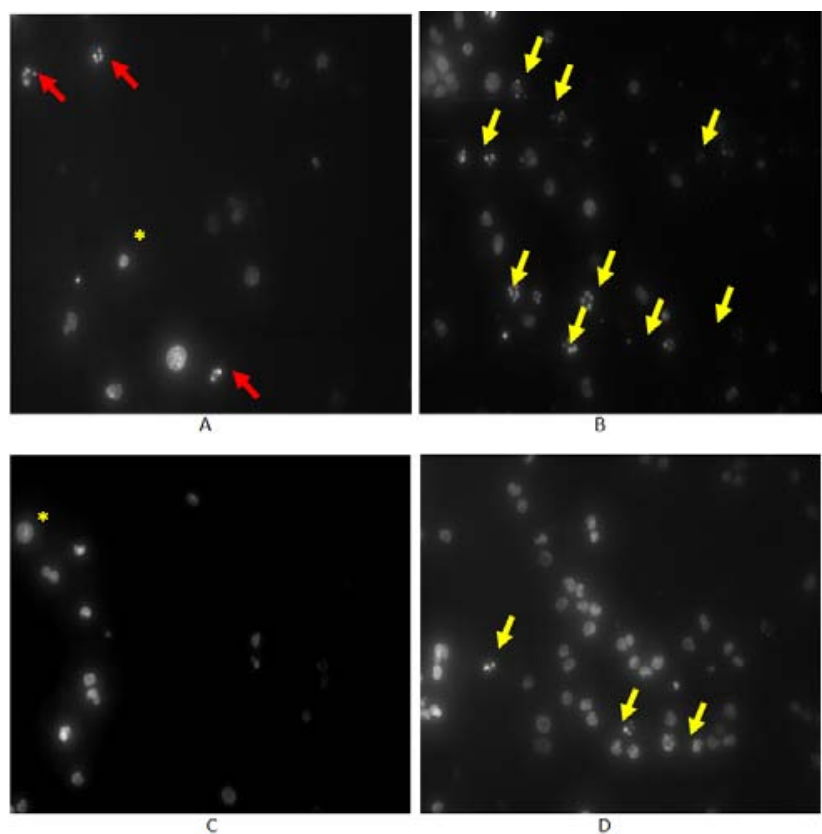

Fig. 4: Marking of nuclei of tumors cells incubated with A dans une nvl ligne. Marking of nuclei of the tumor cell line HUT-78 by the hoechst dye in the absence of sample (control). Note the presence of few cells with nuclear fragmentation (red arrow) Other cells had normal morphology. B: Marking of nuclei of the tumor cell line HUT-78 by the hoechst dye in the presence of the aqueous extract $50 \mu \mathrm{g} / \mathrm{ml}$ : The apoptotic cells appeared

condensed and fragmented. We noticed a very bright color corresponding to condensed/fragmented chromatin. Percentage of apoptotic nuclei identified by hoechst staining was about $42 \%$. Cells that did not fluoresce had normal morphology. C: Marking of nuclei of the tumor line SEAX by the hoechst dye in the absence of sample (control). The cells had normal morphology. D: Marking of nuclei of the tumor line SEAX by the hoechst dye in the presence of the aqueous extract at $50 \mu \mathrm{g} / \mathrm{ml}$ : we revealed the presence of cells with a very bright condensed chromatin and fragmented nucleus. The average rate of apoptotic cells was around ajouter un point

Effects of the two extracts on the expression of the metalloproteinase MMP-9

To assess whether the nuclear textural and DNA changes were associated with modifications in MMP secretion, cells were incubated with the gastropod extracts as described above and the cultured media harvested at $24 \mathrm{~h}$ tested for MMP-9 activities by gel zymography (fig. 5). HUT-78 naturally expressed the MMP-9 protease under the pro-form of $92 \mathrm{kDa}$, whereas no protease activity was observed in the cultured media from untreated SeAx cells. Furthermore, no changes in MMP-9 secretion were observed in both HUT-78 and SeAx cells treated with the $\mathrm{AE}$ and $\mathrm{HAE}$ extracts whatever the concentration used (fig. 5A/B and 5C/D respectively).

To further confirm this lack of effects of the AE and HAE extracts, MMP-9 secretion from HUT-78 and SeAx cells was also analyzed after treatment with two cytokines used as positive control (CXCL10: Recombinant Human CXCL10/IP-10 Protein-RandD systems-266-IP and IL-17: Recombinant Human IL-17/IL-17ARandD systems-317-ILB). CXCL10 induced a mild increase of MMP-9 secretion from HUT-78 cells, while the effects of IL-17 on MMP-9 secretion were more pronounced in these cells, 
definitively suggesting that the secretion of MMP-9 was not affected by the gastropod extracts (fig. 5E). Nevertheless, none of the positive controls was able to induce MMP-9 secretion from the SeAx cell type (fig. 5E) showing that this protease is not expressed by these cells.
Cells were cultured for $24 \mathrm{~h}$ and conditioned media were used for the measurement of MMP-9 activities by gelatin zymography. A and $\mathrm{B}$ are representative gel zymography performed with HUT-78 while $C$ and $D$ are representative of experiments performed with SeAx cells.
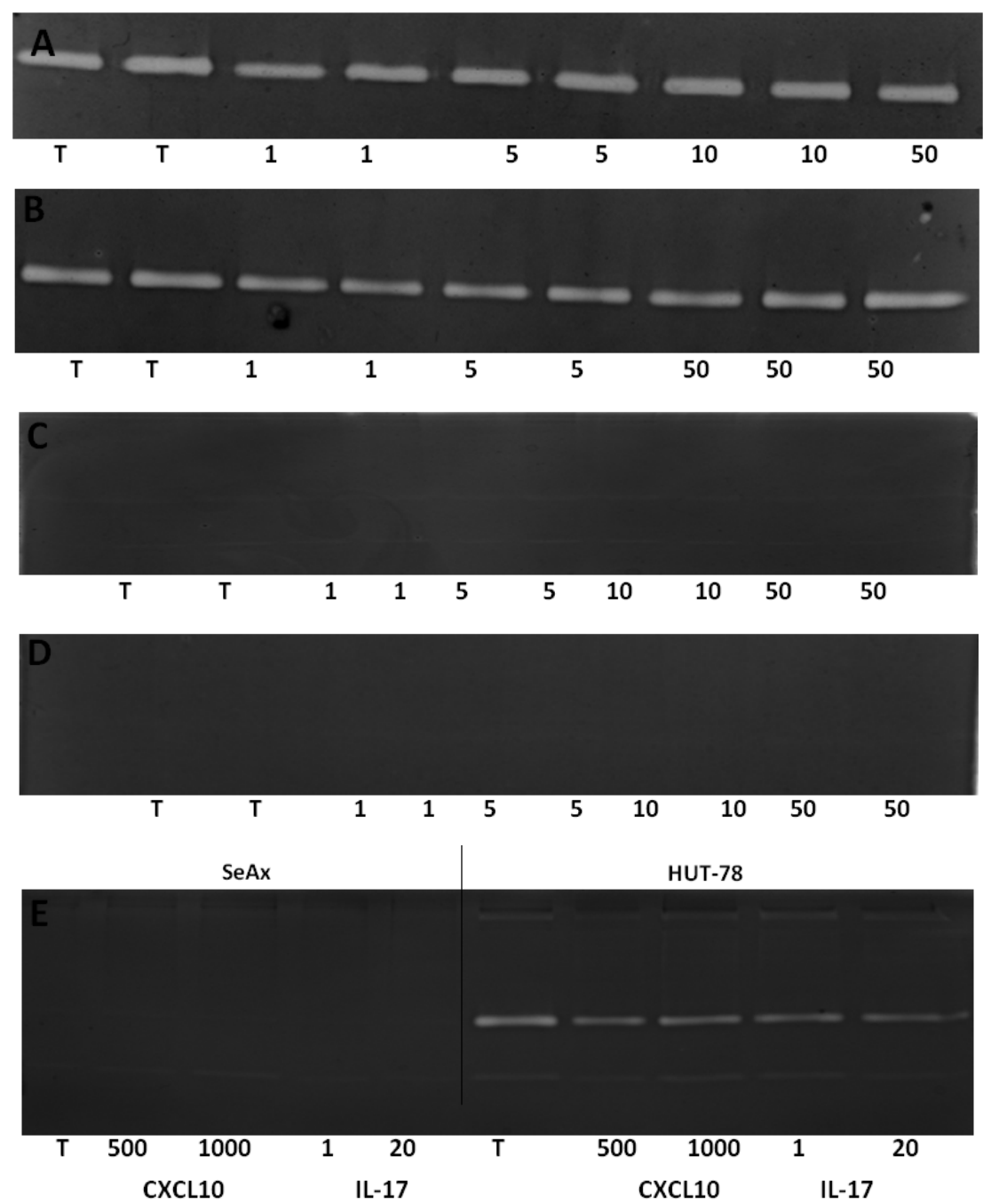

Fig. 5: Gelatin zymography analysis of MMP-9 in different groups, A: Wells 1-2: HUT-78 control, wells 3-4: HUT-78/aqueous extract 1 $\mu \mathrm{g} / \mathrm{ml}$, wells 5-6: HUT-78/aqueous extract $5 \mu \mathrm{g} / \mathrm{ml}$, wells 7-8: HUT-78/aqueous extract $10 \mu \mathrm{g} / \mathrm{ml}$, wells 9-10: HUT-78/aqueous extract 50 $\mu \mathrm{g} / \mathrm{ml}$. B: Wells 1-2: HUT-78 control, wells 3-4: HUT-78/hydroalcoholic extract $1 \mu \mathrm{g} / \mathrm{ml}$, wells 5-6: HUT-78/hydroalcoholic extract 5 $\mu \mathrm{g} / \mathrm{ml}$, wells 7-8-9: HUT-78/hydroalcoholic extract $50 \mu \mathrm{g} / \mathrm{ml}$. C: wells 1-2: SeAx control, wells 3-4: SeAx/aqueous extract $1 \mu \mathrm{g} / \mathrm{ml}$, wells 5-

6: SeAx/aqueous extract $5 \mu \mathrm{g} / \mathrm{ml}$, wells 7-8: SeAx/aqueous extract $10 \mu \mathrm{g} / \mathrm{ml}$, wells 9-10: SeAx/aqueous extract 50 $\mu \mathrm{g} / \mathrm{ml}$. D: Wells 1-2:

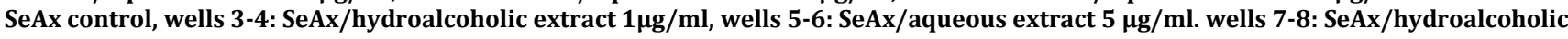
extract $1 \mu \mathrm{g} / \mathrm{ml}$, wells 9-10: SeAx/hydroalcoholic extract $50 \mu \mathrm{g} / \mathrm{ml}$. E: Well 1: SeAx Control, well 2: SeAx/CXCL10 $500 \mathrm{pg} / \mathrm{ml}, \mathrm{well} 3$ :

SeAx/CXCL10 (1000 pg/ml), well 4: SeAx/IL 17 (1 ng/ml), well 5: SeAx/IL-17 (20 ng/ml), well 6: HUT-78 control, well 7: Hut-78/CXCL10 (500 pg/ml), well 8: HUT-78/CXCL10 (1000 pg/ml), well 9: HUT-78/IL-17 (1 ng/ml), well 10: HUT-78/IL-17 (20 ng/ml).

\section{DISCUSSION}

The two extracts $\mathrm{AE}$ and HAE prepared from the gastropod Helix aspersa, showed a toxic activity against both tumor lines analyzed. Indeed, the counting using trypan blue showed that the aqueous extract with the dose of $50 \mu \mathrm{g} / \mathrm{ml}$ induced $44.09 \pm 3.89 \%,(p=0.003)$ mortality in the tumor line HUT-78 and $31.47 \pm 2.96 \%,(p=0.003)$ in the tumor line SEAX. While the alcoholic extract with the same concentration of $50 \mu \mathrm{g} / \mathrm{ml}$ induced $29.90 \pm 5.98 \%$, ( $\mathrm{p}=0.013)$ death of HUT-78 line and $25 \pm 5.57 \%,(p=0.016)$ for the second SEAX cell line. These results showed that both extracts of the mollusk have similar toxic activity against these two tumor cell lines. The aqueous extract induced apoptosis in tumor cells. This was demonstrated by typical changes in morphology of the cells incubated with the aqueous extract such as condensation of chromatin and its fragmentation observed by hoechst dye. Apoptosis can be induced through the activation of death receptors which in turn results in the recruitment of specialized adaptor proteins and activation of caspase cascades. El ouar et al, 2013, found that the aqueous extract of Helix aspersa was highly toxic against tumor cells of breast cancer; the same extract decreased the Bcl-2 levels in the tumor line Hs578T. They found that the extract induces necrosis in these tumor cells [15]

The aqueous extract contains highly polar molecules such as proteins, salts and peptides. Whereas, the hydroalcoholic extract contains less polar products such as alcohols, phenols and amines. For instances, that both extract contains different active molecule that alter cancer cell viability. The determination of total protein and 
total phenols content in the two extracts showed that the aqueous extract contained $4.53 \pm 0.48 \mathrm{mg} / \mathrm{ml}$ of protein and $2.44 \pm 0.11 \mathrm{mg}$ GAE g-1 of phenols while the hydroalcoholic extract contained $1.83 \pm 0.23 \mathrm{mg} / \mathrm{ml}$ of protein and $2.81 \pm 0.16 \mathrm{mg} \mathrm{GAE}$ g- 1 of phenols. Polyphenols are secondary metabolic products belonging to a family of organic molecules characterized as their name suggests, by the presence of several phenolic groups. The data regarding total phenolic content in the foot of Helix aspersa is relatively limited.

Those results showed that the cytotoxic effect exerted by the two extracts may be due to proteins, peptides or phenols contained in theses extracts and that are able to induce apoptosis in the tumor cell lines (HUT-78 and SeAx).

A research team has isolated and identified peptides from several shellfish of marine snail belonging to the genus Conus ananya such as the contoxine [16]. These peptides had several effects; they display anti mitotic effect by inhibiting microtubule assembly and polymerization blocking cancer cells in metaphase [17], an antitumor effect by inducing a disturbance in the lysosomal function which leads cell to cell death [18]. They also block the expression of some enzymes involved in DNA replication and cellular proliferation and therefore they inhibit the growth and tumor invasion [19]. Another research team has identified a glycosaminoglycan in the flesh of the african snail: acharan sulfate [20]. This molecule with a molecular weight of $114 \mathrm{kDa}$ is secreted in response to stimulation [21]. It possesses various biological activities: it inhibits the growth of the tumor in mice implanted with sarcoma cells. This tumor activity may be related to its inhibition of angiogenesis. It inhibitates the expression of fibroblast growth factor and the formation of tubes in vivo induced by VEGF-[22, 23]. Acharan sulfate can also increase the production of cytokines (TNF and IL-1 $\beta$ ), the expression of molecules of co-stimulation $\mathrm{B} 7-1$ and $\mathrm{B} 7-2, \mathrm{CD}_{40}$ and major histocompatibility complex II (MHC II) in vitro by immature dendritic cells [24]. This could explain the anti tumor activity of this molecule in vivo. Others researchers were interested to study biomolecules isolated from marine sponges which the majority of them are cyclic peptides. These molecules are secondary metabolites that possess numerous biological activities including anti-cancer activity $[16,25]$. One of these peptides was tested on tumor lines. Research teams had found that this compound induces apoptosis in these tumor lines by activating caspase- 3 and decreasing the expression of bcl-2 [26, 28]. This same compound had anti mitotic effect by binding to tubulin (microtubules protein, a major component of the cytoskeleton) $[29,30]$.

We know that vascular endothelial growth factor (VEGF) has a role in tumor angiogenesis and is implicated in formation of new vessels, this need a degradation of basal membrane with MMP. The production of MMP-9 by the two tumor lines HUT-78 and SEAX stimulated by aqueous and hydroalcoholic extracts of Helix aspersa is not modified by the two extracts used at different concentrations relative to the control. MMP-9 is a protease expressed in several cancers such as: renal cell carcinoma, [31] and hematological cancers, [32, 33]. There are several transcription factors that regulate the expression of MMP-9: include NFkB, AP-1, AP-2 and SP1 [34]. The inhibition of the production of MMP-9 is regulated by several cytokines via transduction cascade of the JAK/STAT [35].

Currentcurrently our team is interested in evaluating the in vivo effects of our other extracts such as anti-ulcer effects experienced by other researchers, [36] and also protective effects against chemoinduced hepatotoxicity in animal models [37].

The lack of in vitro effects of extracts indicates that the different molecules contained in the two extracts did not induce any changes at the molecular level in the transduction cascades which can induce an increase in expression of MMP-9 in line SEAX or which inhibit the production of this protease in tumor line HUT-78. We could say that our extracts have not an angiogenic effect by activation of MMP-9.

\section{CONCLUSION}

In conclusion, our results demonstrate that both extracts prepared from the terrestrial gastropod Helix aspersa had a cytotoxic effect on CTCL studied by increasing mortality. It is possible that the extracts induce apoptosis in tumor cells by stimulating the NFkB pathway, activating the Bax gene, reducing the intensity of the intracellular survival signals or by inhibiting the phosphorylation of signaling pathway proteins cell survival. However, these extracts had no effect on the expression of MMP-9 in these CTCL.

Our work is only a preliminary study to test in vitro toxic effects of extracts of terrestrial snail Helix aspersa. Others works in vivo are in progress. Another comprehensive study will be interesting to show the mechanism of action of bioactive molecules after purification. For instance, their effects on the expression of protein kinases of different signal transduction pathways that are involved in expression of an antiapoptotic or proapoptotic process such as Bcl-2 and Bax, NFkB, P53 in tumor lines HUT-78 and SEAX and other tumor cell lines and normal cell lines. It will also be very interesting to test also the effect of Helix aspersa extracts on Human umbilical vein endothelial cells (HUVEC) and study the expression of VEGF gene in these cells.

\section{ACKNOWLEDGMENT}

Authors are grateful to Algerian Ministry of High education and Scientific Research for the financial help, they are also grateful to Dr Michel L (INSERM S 976, France) for kindly providing the cell lines.

\section{CONFLICT OF INTERESTS}

All the authors declare they have no conflict of interest. This work has not published previously, and it is not under considerations for publication elsewhere.

\section{REFERENCES}

1. Toader-Williams A, Golubkina N. Investigation upon the edible snail's potential as source of selenium for human health and nutrition observing its food chemical contaminant risk factor with heavy metals. Bull Univ Agric Sci Vet Med Cluj-Napoca Food Sci Technol 2009;66:1-2.

2. Gomot A. Biochemical composition of Helix snails; influence of genetic and physiological factors. J Molluscan Studies 1998;64:173-81.

3. Gross J, Lapiere CM. Collagenolytic activity in amphibian tissues: a tissue culture assay. Proc Natl Acad Sci USA 1962;48:1014-22.

4. Coussens LM, Tinkle CL, Hanahan D, Werb Z. MMP-9 supplied by bone marrow-derived cells contributes to skin carcinogenesis. Cell 2000;103:481-90.

5. Pollard JW. Tumor-educated macrophages promote tumor progression and metastasis. Nat Rev Cancer 2004;4:71-8.

6. Antonicelli F, Vallerand D, Trussardi-Regnier A, Grange F, Hornebeck W, Bernard P. Regulation of MMPs during melanoma progression. from genetic to epigenetic. Anticancer Agents Med Chem 2012;7:773-82.

7. Hanahan D, Weiberg RA. The Hallmarks of cancer. Cell 2000;100:57-70.

8. Egeblad M, Werb Z. New functions of metalloproteinases in cancer progression. Nat Rev Cancer 2002;2:161-74.

9. Overall CM, Kleifield O. Tumor microenvironement-opinion: validating matrix metalloproteinases as drug target and antitarget for cancer therapy. Nat Rev Cancer 2006;6:227-39.

10. Esteve PO, Tremblay P, Houde M, St-Pierre Y, Mandeville R. In vitro expression of MMP-2 and MMP-9 in glioma cells following exposure to inflammatory mediators. Biochim Biophys Acta 1998;1403:85-96

11. Kossakowska AE, Urbanski S, Huchcroft SA, Edwards DR. Relationship between the clinical aggressiveness of large cell immunoblastic lymphomas and expression of $92 \mathrm{kDa}$ gelatinase (type IV collagenase) and tissue inhibitor of metalloproteinases-1 (TIMP-1) RNAs. Oncol Res 1992;4:233-40.

12. El-Wahidi M, El-Amraoui B, Biard JF, Uriz MJ, Fassouane A, Bamhaoud $T$. Variation saisonnière et géographique de l'activité antifongique des extraits de deux éponges marines récoltées sur le littoral atlantique d'El Jadida, Maroc. J Med Mycol 2011;21:28-32.

13. Bradford MM. A rapid and sensitive method for the quantitation of microgram quantities of protein utilizing the principle of protein-dye binding. Anal Biochem 1976;72:248-54. 
14. Vermerris W, Nicholson R. Phenolic compound biochemistry. USA: Springer Nueva york, EEUU; 2006;316:151-3.

15. El Ouar I, Braicu C, Naimi D, Irimie A, Berindan-Neagoe I. Anti tumour effect of aqueous extract from Helix aspersa. Int J Pharm Biol Sci 2013;4:1325-32.

16. Malaker A, Ahmad SAI. Therapeutic potency of anticancer peptides derived from marine organism. Int J Eng Appl Sci 2013;2:35-65.

17. Poncet J. The dolastatins, a family of promising antineoplastic agents. Curr Pharm Des 1999;5:139-62.

18. García-Rocha M, Bonay P, Avila J. The antitumoral compound Kahalalide F acts on cell lysosomes. Cancer Lett 1996;99:43-50.

19. Martín-Algarra S, Espinosa E, Rubió J, López JJL, Manzano JL, Carrión LA, et al. Phase II study of weekly Kahalalide F in patients with advanced malignant melanoma. Eur J Cancer 2009;45:732-5

20. Kim SY, Jo YY, Chang IM, Toida T, Parks Y, Linhardt RJ. A new glycosaminoglycan from the giant African snail Achatina fulica. J Biol Chem 1996;271:11750-5.

21. Jeong J, Toida T, Muneta Y, Kosiishi I, Imanari T, Linhardt RJ, et al. Localization and characterization of acharan sulfate in the body of the giant African snail Achatina fulica. Comp Biochem Physiol Part B: Biochem Mol Biol 2001; 130: 513-9.

22. Ghosh AK, Hirasawa N, Lee YS, Kim YS, Shin KH, Ryu N, et al. Inhibition by acharan sulfate of angiogenesis in experimental inflammation models. Br J Pharmacol 2002;137:441-8.

23. Lee YS, Yang HO, Shin KH, Choi HS, Jung SH, Kim YM, et al. Suppression of tumor growth by a new glycosaminoglycan isolated from the African giant snail Achatina fulica. Eur J Pharmacol 2003;465:191-8.

24. Kim HS, Lee YH, Lee YR, Sun-A Im, Lee JK, Kim YS, et al. Activation of professional antigen presenting cells by acharan sulfate isolated from giant african snail, Achatina fulica. Arch Pharmacal Res 2007;30:866-70.

25. Valentin Bhimba B, Cindhu M, Vinod V. Efficacy of bioactive compound extracted from marine sponge Haliclona exigua. Asian J Pharm Clin Res 2013:6 Suppl 2:347-9.

26. Braekman JC, Daloze D, Moussiaux B, Riccio R. Jaspamide from the marine sponge Jaspis johnstoni. J Nat Prod 1987;50:994-5.

27. Odaka C, Sanders ML, Crews P. Jasplakinolide induces apoptosis in various transformed cell lines by a caspase-3-like protease-dependent pathway. Clin Diagn Lab Immunol 2000;7:947-52.
28. Cioca DP, Kitano K. Induction of apoptosis and CD10/neutral endopeptidase expression by jaspamide in HL-60 line cells. Cell Mol Life Sci 2002;59:1377-87.

29. Gamble WR, Durso NA, Fuller RW, Westergaard CK, Johnson TR, Sackett L, et al. Cytotoxic and tubulin-interactive hemiasterlins from Auletta sp. and Siphonochalina spp. sponges. Bioorg Med Chem 1999;7:1611-5.

30. Loganzo F, Discafani CM, Annable T, Beyer C, Musto S, Hari M, et al. HTI-286. A synthetic analogue of the tripeptide hemiasterlin, is a potent antimicrotubule agent that circumvents P-glycoprotein-mediated resistance in vitro and in vivo. Cancer Res 2003;63:1838-45.

31. Perrin C, Patard JJ, Jouan F, Collet N, Théoleyre S, Edeline J, et al. La neutrophil gelatinase-associated lipocalin, ou LCN 2, facteur d'agressivité dans le carcinome rénal à cellules claires (CRCC). Prog Urol 2011;21:851-8.

32. Guérin M, Thérien C, Krosl G, Roy DC. Synthetic 15-Mer peptide (pck3145) derived from prostate secretory protein has in vitro and in vivo activity against non-hodgkin's lymphoma and other hematologic malignancies. Blood 2007;110:1388.

33. Roy JS, Van Themsch S, Demers M, Opdenakke G, Arnold B. Triggering of T-cell leukemia and dissemination of T-cell lymphoma in MMP-9-deficient Mice. Leukemia 2007;12:2506-11.

34. St-Pierre Y, Couillard J, Van Temsch C. Regulation of MMP-9 gene expression for the development of novel molecular targets against cancer and inflammatory diseases. Expert Opin Ther Targets 2004;8:473-89.

35. Ramana CV, Chatterjee-Kishore M, Nguyen H, Stark GR. Complex role of stat 1 in regulating gene expression. Oncogene 2000;19:2619-27.

36. Abdel-Rahim IT, Bamagous GA, Omran GA. Anti-ulcerogenic effect of Genistein against indomethacin-induced gastric ulcer in rats. Asian J Pharm Clin Res 2016;9:58-63.

37. Singh G, Dhadwal N, SLH. Experimental models for hepatotoxicity. Asian J Pharm Clin Res 2015;8:70-4.

\section{How to cite this article}

- Mebirouk Romeila, Naimi Dalila, Riani Meriem, Antonicelli Frank. Comparative study of two Helix aspersa extracts on tumor cell lines (Hut-78 and Seax) proliferation and MMP-9 secretion. Int J Pharm Pharm Sci 2016;8(11):288-293. 